Review

\title{
Nanoparticle albumin-bound paclitaxel as neoadjuvant chemotherapy of breast cancer: a systematic review and meta- analysis
}

\author{
Yu Zong ${ }^{1}$, Jiayi $\mathbf{W u}^{1}$ and Kunwei Shen ${ }^{1}$ \\ ${ }^{1}$ Comprehensive Breast Health Center, Shanghai Ruijin Hospital affiliated to Shanghai Jiaotong University School of Medicine, \\ Shanghai, China \\ Correspondence to: Kunwei Shen, email: kwshen@medmail.com.cn \\ Keywords: breast cancer; neoadjuvant; nab-paclitaxel; pathological complete response; toxicity \\ Received: October 21, $2016 \quad$ Accepted: December 08, $2016 \quad$ Published: January 03, 2017
}

\section{ABSTRACT}

Background: The value of nanoparticle albumin-bound paclitaxel (nab-paclitaxel) in neoadjuvant systemic therapy for breast cancer remains uncertain.

Methods: Both electronic databases and proceedings of oncologic meetings were included in systematic literature search. Pooled rates of pathological complete response ( $P C R$ ), odds ratios (ORs) and $95 \%$ confidence intervals (CIs) were calculated using fixed-effect or random-effect model to determine the effect of neoadjuvant nabpaclitaxel.

Results: Twenty-one studies with 2357 patients were included, 3 of which were randomized clinical trials. The aggregate PCR(ypTO/is ypNO) rate was $32 \%(95 \%$ CI $\mathbf{2 5 - 3 8 \% ) ~ i n ~ u n s e l e c t e d ~ b r e a s t ~ c a n c e r ~ p a t i e n t s ~ a n d ~ v a r i a t e d ~ i n ~ d i f f e r e n t ~ s u b t y p e s . ~}$ Within randomized clinical trials, the probability of achieving PCR was significantly higher in the nab-paclitaxel group than in the conventional taxanes group (OR = $1.383,95 \%$ CI 1.141-1.676, $p=0.001$ ). For non-hematological toxic effect, any grade and grade 3-4 peripheral sensory neuropathy occurred more frequently with nabpaclitaxel compared to paclitaxel (any grade, OR $=2.090,95 \%$ CI 1.016-4.302, $p=$ 0.045 ; grade3-4, OR = 3.766, 95\%CI 2.324-6.100, $p<0.001$ ). Hypersensitivity was more common with paclitaxel than nab-paclitaxel at any grade and grade 3-4.

Conclusion: nab-paclitaxel is an effective cytotoxic drug in neoadjuvant treatment of breast cancer, especially for aggressive tumors in terms of pCR. Exchange of nab-paclitaxel for conventional taxanes could significantly improve pCR rate with reasonable toxicities.

\section{INTRODUCTION}

Breast cancer is the most common malignancy in women worldwide, and one of the leading causes of cancer death [1]. In routine clinical practice, neoadjuvant systemic therapy (NST) has become a widely accepted choice to treat patients with operable and locally advanced breast cancer [2]. Patients attained pathologic complete response (pCR) after NST have significantly improved long-term survival when compared to those did not $[3,4]$.

Taxanes are essential in the adjuvant treatment of lymph-node-positive or high-risk, lymph-node-negative breast cancer [5], and also significantly increased clinical response and $\mathrm{pCR}$ rates for operable breast cancer in the neoadjuvant setting [6]. Paclitaxel is one of the most widely used taxanes in breast cancer treatment. Neoadjuvant paclitaxel significantly increased tumor response, and improved survival outcome in those patients who achieved pCR [7-13]. However, paclitaxel contains a combination of polyethylated castor oil and ethanol as the solvents to increase drug solubility, which causes solvent-related toxicities such as hypersensitivity reactions and prolonged peripheral neuropathy $[14,15]$. Clinically, paclitaxel should be administered with steroid and antihistamine prophylaxis over a prolonged period of time (3 hours).

Nanoparticle albumin-bound paclitaxel (nabpaclitaxel) is a novel nanometersized particle initially developed to avoid the toxicities associated with polyethylated castor oil [16]. It has been hypothesized 
that albumin-mediated delivery may result in enhanced transport of nab-paclitaxel to tumors [17] and improved tolerability profile of nab-paclitaxel compared with that of paclitaxel at equimolar doses, with shorter infusion schedules (30 minutes) and no premedication [16]. In a pivotal phase III trial of patients with metastatic breast cancer(MBC), nab-paclitaxel at a dose of $260 \mathrm{mg} / \mathrm{m}^{2}$ has been shown to achieve higher response rates and longer time to progression compared to paclitaxel $175 \mathrm{mg} / \mathrm{m}^{2}$ (both given every 3 weeks) [18]. The safety profiles of nab-paclitaxel were acceptable in most early trials [19-21], but the data of head-to-head comparison between nabpaclitaxel and paclitaxel is still lacking.

However, in a curative breast cancer setting, no data is available on whether nab-paclitaxel is equivalent or even superior to conventional taxanes (paclitaxel, docetaxel). Several neoadjuvant clinical trials investigated safety and efficacy of nab-paclitaxel-based regimens in operable/locally advanced breast cancer patients. It was hard to interpret all the information into a clear conclusion in terms of the value of nab-paclitaxel in neoadjuvant setting due to: 1) Most of the studies were single-arm, non-randomized phase II trials with rather small sample size, 2) disease subtypes varied among studies, 3) variable study designs regarding to different dose, schedule, drug combination of nab-paclitaxel, 4) different definitions of pCR. Therefore, by reviewing all the neoadjuvant nab-paclitaxel-related studies to date, we performed this meta-analysis with the aim to 1) assess the efficacy of nab-paclitaxel in unselected patients as well as in various intrinsic breast cancer subtypes with specific pCR definitions, 2) to compare efficacy and toxicity of nabpaclitaxel to conventional taxane regimens in neoadjuvant breast cancer treatment.

\section{RESULTS}

\section{Literature search results}

Our literature search yielded 184 relevant records. Twenty-one studies (11 articles and 10 conference abstracts), including 2357 patients who had been treated with neoadjuvant nab-paclitaxel, met the inclusion criteria and were eventually selected for meta-analysis (Figure 1). Eligible trials enrolled patients between 2010 and 2016.

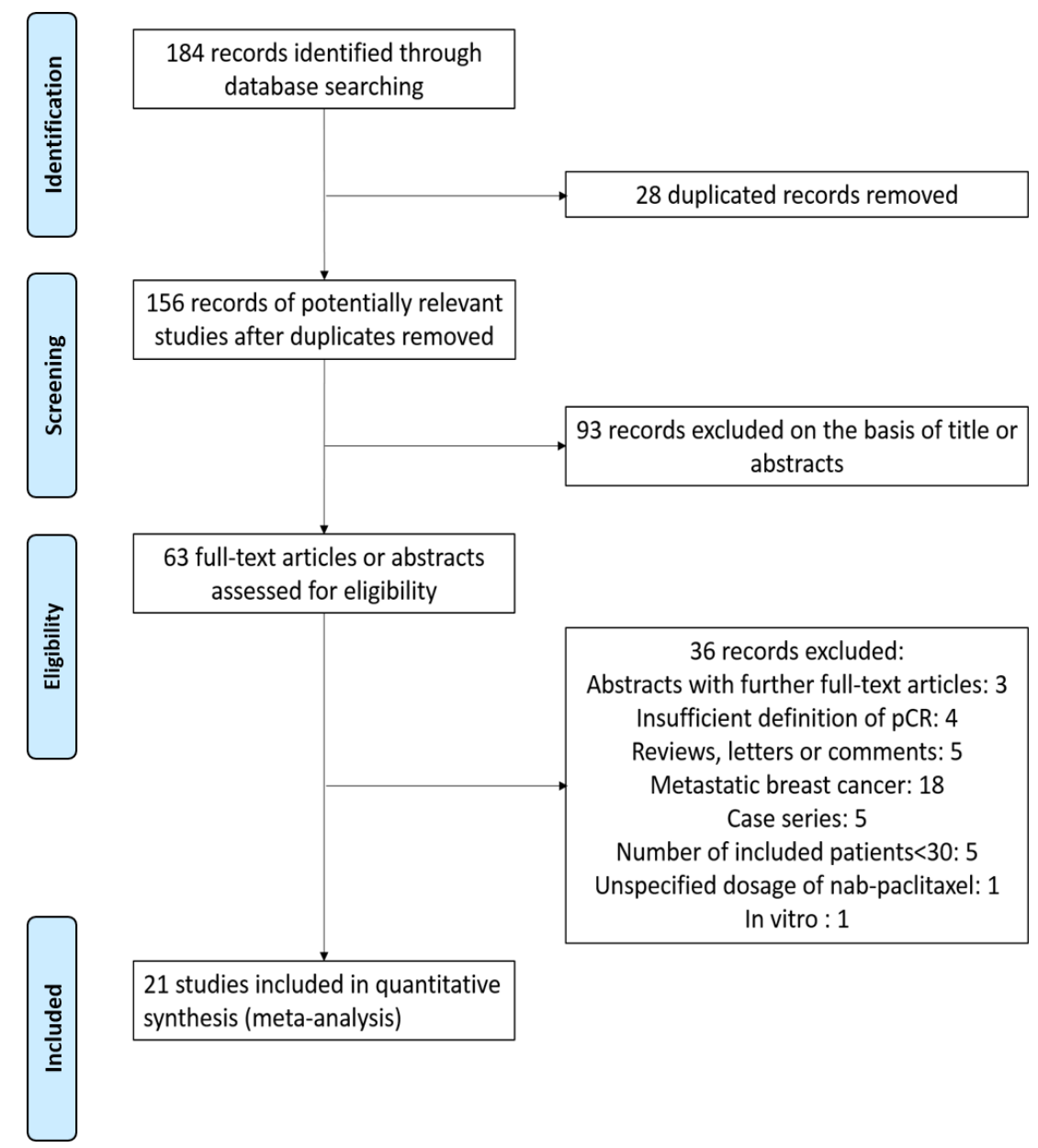

Figure 1: The flow chart summarizing the process for the identification of the eligible studies. 
Table 1: Baseline characteristics of the included studies.

\begin{tabular}{|c|c|c|c|c|c|c|c|c|c|}
\hline Study & Year & Phase & $\mathbf{N}$ & Population & Stage & Neoadjuvant Regimens & Nab-paclitaxel dosage & Definition of pCR & pCR rate(\%) \\
\hline Robidoux[22] & 2010 & II & 65 & all & IIB-IIIB & nab-P(H) $\rightarrow \mathrm{FEC}(\mathrm{H})$ & $100 \mathrm{mg}, \mathrm{qw}^{*} 12$ & $\begin{array}{l}\text { ypT0/is ypN0 } \\
\text { ypT0/is ypN0/+ }\end{array}$ & $\begin{array}{l}26.2 \\
29.2\end{array}$ \\
\hline Yardley[23] & 2010 & II & 116 & all & II-III & nab-P + Gem $+E$ & $175 \mathrm{mg}, \mathrm{q} 2 \mathrm{w} * 6$ & урT0 ypN0 & 19.8 \\
\hline Sinclair[24] & 2012 & II & 55 & HER2- & II-III & nab-P+Cb+bev $(\rightarrow$ ddAC + bev $)$ & $100 \mathrm{mg}, \mathrm{qw}^{*} 12$ & ypT0/is ypNo & 34.5 \\
\hline $\operatorname{Li}[25]$ & 2012 & II & 54 & all & II-III & $\mathrm{ddAC}(\mathrm{H}) \rightarrow$ nab-P+Cb$(\mathrm{H})$ & $100 \mathrm{mg}, \mathrm{d} 1,8,15, \mathrm{q} 4 \mathrm{w} * 3$ & ypT0/is ypN0 & 27.8 \\
\hline Snider[26] & 2013 & II & 30 & $\mathrm{TN}$ & $\geq 2 \mathrm{~cm}$ & nab-P+Cb+bev $\rightarrow \mathrm{AC}+$ bev & $100 \mathrm{mg}, \mathrm{d} 1,8,15, \mathrm{q} 4 \mathrm{w} * 4$ & $\begin{array}{l}\text { ypT0/is ypN0 } \\
\text { ypT0/is ypN0/+ }\end{array}$ & $\begin{array}{l}53.3 \\
56.7\end{array}$ \\
\hline Sinclair[27] & 2013 & II & 53 & HER $2+$ & II-III & nab- $\mathrm{P} \rightarrow \mathrm{Cb}$ & $100 \mathrm{mg}, \mathrm{qw}^{*} 18$ & ypT0/is ypN0 & 45.3 \\
\hline Mrozek[28] & 2014 & II & 33 & HER2- & II-III & nab-P+Cb+bev & $100 \mathrm{mg}, \mathrm{d} 1,8,15, \mathrm{q} 4 \mathrm{w} * 6$ & ypT0/is ypN0 & 18.2 \\
\hline Shimada[29] & 2015 & NR & 53 & HER2- & II-III & nab-P $\rightarrow$ EC & $260 \mathrm{mg}, \mathrm{q} 3 \mathrm{w}^{*} 4$ & $\begin{array}{l}\text { ypT0/is ypN0 } \\
\text { ypT0/is ypN0/+ }\end{array}$ & $\begin{array}{l}3.8 \\
5.7\end{array}$ \\
\hline Connolly[30] & 2015 & II & 62 & $\begin{array}{l}\text { HER2-, } \\
\text { Grade 2/3 }\end{array}$ & $\begin{array}{l}\text { T1c, N1-3 or } \\
\text { T2-4, any N, }\end{array}$ & nab- $\mathrm{P}+\mathrm{Cb}+/$-vorinostat & $100 \mathrm{mg}, \mathrm{qw}^{*} 12$ & ypT0/is ypN0 & 27.4 \\
\hline Huang[31] & 2015 & II & 30 & all & II-III & nab- $\mathrm{P}+\mathrm{Cb}(\mathrm{H})$ & $125 \mathrm{mg}, \mathrm{qw}^{*} 12$ & ypT0/is ypNo & 26.7 \\
\hline Tanaka[32] & 2015 & II & 45 & HER 2+ & I-IIIA & $\mathrm{EC} / \mathrm{FEC} \rightarrow$ nab-P+H & $260 \mathrm{mg}, \mathrm{q} 3 \mathrm{w} * 4$ & ypT0/is ypNo & 48.9 \\
\hline Gluz[33] & 2015 & II & 324 & $\mathrm{TN}$ & T1c-T4, any $\mathrm{N}$ & nab-P+Cb/Gem & $125 \mathrm{mg}, \mathrm{d} 1,8, \mathrm{q} 3 \mathrm{w}^{*} 3$ & ypT0/is ypN0 & 36.4 \\
\hline \multirow[t]{2}{*}{ Kuwayama[34] } & 2015 & II & 75 & HER2- & II-III & nab-P $\rightarrow$ FEC & $100 \mathrm{mg}, \mathrm{d} 1,8,15, \mathrm{q} 4 \mathrm{w} * 4$ & ypT0/is ypN0 & 17.3 \\
\hline & & & 77 & & & $\mathrm{~T} \rightarrow \mathrm{FEC}$ & & ypT0/is ypNo & 11.7 \\
\hline Khan[35] & 2015 & II & 32 & HER2- & II-III & nab- $\mathrm{P}+\mathrm{H} \rightarrow \mathrm{AC}$ & $100 \mathrm{mg}, \mathrm{qw}^{*} 12$ & ypT0/is ypN0 & 21.9 \\
\hline Shigematsu[36] & 2015 & II & 54 & all & T1c-3N0-2 & nab-P $+\mathrm{C}(\mathrm{H}) \rightarrow \mathrm{FEC}$ & $260 \mathrm{mg}, \mathrm{q} 3 \mathrm{w}^{*} 4$ & $\begin{array}{l}\text { ypT0/is ypN0 } \\
\text { ypT0/is ypN0/+ }\end{array}$ & $\begin{array}{l}37.0 \\
38.9\end{array}$ \\
\hline Somlo[37] & 2015 & NR & 38 & $\mathrm{TN}$ & II-III & nab- $\mathrm{P}+\mathrm{Cb}$ & $80 \mathrm{mg}, \mathrm{qw}^{*} 16$ & ypT0/is ypNo & 52.6 \\
\hline \multirow[t]{2}{*}{ Untch[38] } & 2016 & III & 606 & all & $\begin{array}{l}>2 \mathrm{~cm} \text { or } 1-2 \mathrm{~cm} \\
\text { and high risk }\end{array}$ & nab-P(H+Per $) \rightarrow \mathrm{EC}(\mathrm{H}+\mathrm{Per})$ & $150-125 \mathrm{mg}, \mathrm{qw}^{*} 12$ & $\begin{array}{l}\text { ypT0/is ypN0 } \\
\text { ypT0/is ypN0/+ } \\
\text { ypT0 ypN0 }\end{array}$ & $\begin{array}{l}42.7 \\
48.7 \\
38.4 \\
\end{array}$ \\
\hline & & & 600 & & & $\mathrm{P}(\mathrm{H}+\mathrm{Per}) \rightarrow \mathrm{EC}(\mathrm{H}+\mathrm{Per})$ & & $\begin{array}{l}\text { ypT0/is ypN0 } \\
\text { ypT0/is ypN0/+ } \\
\text { ypT0 ypN0 }\end{array}$ & $\begin{array}{l}34.5 \\
39.7 \\
29.0\end{array}$ \\
\hline \multirow[t]{2}{*}{ Gianni[39] } & 2016 & III & 346 & $\begin{array}{l}\text { HER2- } \\
\text { (Luminal-B } \\
\text { or TN) } \\
\end{array}$ & $\mathrm{T} 2-4, \mathrm{~N} 0-3$ & nab-P $\rightarrow \mathrm{A}(\mathrm{E}) \mathrm{C} / \mathrm{FEC}$ & $125 \mathrm{mg}, \mathrm{d} 1,8,15, \mathrm{q} 4 \mathrm{w}^{*} 4$ & ypT0/is ypN0 & 22.5 \\
\hline & & & 349 & & & $\mathrm{P} \rightarrow \mathrm{A}(\mathrm{E}) \mathrm{C} / \mathrm{FEC}$ & & ypT0/is ypN0 & 18.6 \\
\hline Matsuda[40] & 2016 & II & 35 & HER2- & NR & $\begin{array}{l}\text { panitumumab } \rightarrow \text { panitumumab } \\
+ \text { nab-P }+\mathrm{Cb} \rightarrow \text { FEC }\end{array}$ & $100 \mathrm{mg}, \mathrm{d} 1,8,15, \mathrm{q} 4 \mathrm{w} * 4$ & ypT0/is ypN0 & 28.6 \\
\hline Khasraw[41] & 2016 & NR & 40 & all & II-III & $\mathrm{EC} \rightarrow$ nab-P(H) & $125 \mathrm{mg}, \mathrm{d} 1,8,15, \mathrm{q} 4 \mathrm{w} * 4$ & $\begin{array}{l}\text { ypT0/is ypN0 } \\
\text { ypT0/is ypN0/+ }\end{array}$ & $\begin{array}{l}47.5 \\
55.0\end{array}$ \\
\hline Nahleh[42] & 2016 & II & 211 & HER2- & IIB-IIIC & nab-P(+/-bev $) \rightarrow$ ddAC & $100 \mathrm{mg}, \mathrm{qw}^{*} 12$ & ypT0/is ypN0 & 28.0 \\
\hline
\end{tabular}

Abbreviations: nab-P, nab-paclitaxel; pCR, pathologic complete response; NR, not reported; HER2, human epidermal growth factor receptor 2; TN, triple negative; qw, once weekly; q2w, every 2 weeks; q3w, every 3 weeks; q4w, every 4 weeks; H, trastuzumab; FEC, fluorouracil/epirubicin/cyclophosphamide; $\mathrm{Cb}$, carboplatin; bev, bevacizumab; dd, dose dense; AC, doxorubicin/cyclophosphamide; EC, epirubicin/cyclophosphamide; Gem, gemcitabine; T, docetaxel; Per, pertuzumab; P, paclitaxel; ypT0/is ypN0, absence of invasive cancer in the breast and axillary nodes; ypT0/is ypN0/+, absence of invasive cancer in the breast, irrespective of nodal involvement; ypT0 ypN0, absence of invasive cancer and in situ cancer in the breast and axillary nodes.

\section{Trial characteristics and treatment details}

Main characteristics of included trials were listed in Table 1. Twenty studies reported pCR outcomes with the definition of ypT0/is ypN0 (absence of residual invasive cancer within both the breast and lymph nodes, noninvasive breast residuals allowed), while 6 using ypT0/ is ypNO/+ (absence of invasive breast cancer in the breast only) and 2 using ypT0 ypN0 (complete eradication of all invasive and noninvasive cancer), respectively. Subgroup analysis according to disease subtypes was conducted in studies whose pCR defined as ypT0/is ypN0. Three randomized studies [43, 47, 48] comparing efficacy of nab-paclitaxel to conventional taxane regimens (paclitaxel or docetaxel) were included in our meta-analysis. Toxicity analyses were also performed within randomized controlled trials $[47,48]$.

\section{pCR after neoadjuvant nab-paclitaxel in unselected population}

Overall frequency of pCR was quite satisfying in unselected breast cancer patients treated with neoadjuvant nab-paclitaxel-based regimens. pCR (ypT0/is ypN0) rates 
Table2: Safety analysis of nab-paclitaxel compared to paclitaxel (total $N=1878$ ).

\begin{tabular}{|c|c|c|c|c|c|c|c|c|}
\hline \multirow[b]{2}{*}{ Toxicity } & \multicolumn{2}{|c|}{ No. of events } & \multirow[b]{2}{*}{ OR } & \multirow[b]{2}{*}{$95 \%$ CI } & \multirow[b]{2}{*}{$P$ value } & \multirow[b]{2}{*}{ Heterogeneity $\chi^{2}$} & \multirow{2}{*}{$\begin{array}{l}\text { Heterogeneity } p \\
\text { value }\end{array}$} & \multirow[b]{2}{*}{$I^{2}(\%)$} \\
\hline & \begin{tabular}{|l|} 
Nab- \\
paclitaxel
\end{tabular} & Paclitaxel & & & & & & \\
\hline \multicolumn{9}{|c|}{ Neutropenia } \\
\hline Any grade & 672 & 609 & 1.449 & $1.162 \sim 1.809$ & 0.001 & 1.65 & 0.199 & 39.3 \\
\hline Grade $\geq 3$ & 471 & 437 & 1.294 & $0.704 \sim 2.381$ & 0.407 & 8.28 & 0.004 & 87.9 \\
\hline \multicolumn{9}{|l|}{ Leucopenia } \\
\hline Any grade & 642 & 619 & 1.213 & $0.916 \sim 1.607$ & 0.178 & 0.60 & 0.438 & 0 \\
\hline Grade $\geq 3$ & 308 & 295 & 1.066 & $0.863 \sim 1.315$ & 0.554 & 0.13 & 0.718 & 0 \\
\hline \multicolumn{9}{|c|}{$\begin{array}{l}\text { Increased alanine } \\
\text { aminotransferase }\end{array}$} \\
\hline Any grade & 364 & 379 & 0.907 & $0.737 \sim 1.116$ & 0.356 & 1.73 & 0.188 & 42.3 \\
\hline Grade $\geq 3$ & 16 & 17 & 0.655 & $0.114 \sim 3.744$ & 0.634 & 2.56 & 0.109 & 61.0 \\
\hline \multicolumn{9}{|c|}{$\begin{array}{l}\text { Increased aspartate } \\
\text { aminotransferase }\end{array}$} \\
\hline Any grade & 250 & 235 & 1.089 & $0.873 \sim 1.357$ & 0.451 & 1.01 & 0.315 & 0.9 \\
\hline Grade $\geq 3$ & 6 & 6 & 0.994 & $0.334 \sim 2.958$ & 0.991 & 1.48 & 0.224 & 32.5 \\
\hline \multicolumn{9}{|c|}{$\begin{array}{l}\text { Peripheral sensory } \\
\text { neuropathy }\end{array}$} \\
\hline Any grade & 725 & 572 & 2.090 & $1.016 \sim 4.302$ & 0.045 & 12.07 & 0.001 & 91.7 \\
\hline Grade $\geq 3$ & 78 & 22 & 3.766 & $2.324 \sim 6.100$ & $<0.001$ & 0.81 & 0.369 & 0 \\
\hline \multicolumn{9}{|l|}{ Nausea } \\
\hline Any grade & 615 & 612 & 0.995 & $0.821 \sim 1.206$ & 0.963 & 0.02 & 0.900 & 0 \\
\hline Grade $\geq 3$ & 28 & 27 & 1.031 & $0.603 \sim 1.764$ & 0.910 & 0.16 & 0.691 & 0 \\
\hline \multicolumn{9}{|l|}{ Fatigue } \\
\hline Any grade & 616 & 561 & 1.337 & $1.084 \sim 1.648$ & 0.007 & 0.15 & 0.703 & 0 \\
\hline Grade $\geq 3$ & 38 & 29 & 1.316 & 0.804 2.156 & 0.275 & 0.58 & 0.446 & 0 \\
\hline \multicolumn{9}{|l|}{ Vomiting } \\
\hline Any grade & 228 & 206 & 1.132 & $0.913 \sim 1.403$ & 0.259 & 1.17 & 0.280 & 14.3 \\
\hline Grade $\geq 3$ & 21 & 18 & 1.163 & $0.615 \sim 2.199$ & 0.641 & 1.97 & 0.160 & 49.3 \\
\hline \multicolumn{9}{|l|}{ Diarrhea } \\
\hline Any grade & 388 & 345 & 1.174 & 0.877 1.571 & 0.282 & 2.00 & 0.157 & 50.1 \\
\hline Grade $\geq 3$ & 27 & 20 & 1.352 & $0.752 \sim 2.430$ & 0.313 & 0.81 & 0.369 & 0 \\
\hline \multicolumn{9}{|l|}{ Rash } \\
\hline Any grade & 249 & 188 & 1.347 & $0.890 \sim 2.038$ & 0.159 & 2.76 & 0.097 & 63.7 \\
\hline Grade $\geq 3$ & 7 & 7 & 0.710 & $0.063 \sim 7.992$ & 0.782 & 2.47 & 0.116 & 59.5 \\
\hline \multicolumn{9}{|c|}{ Hypersensitivity } \\
\hline Any grade & 107 & 145 & 0.517 & $0.201 \sim 1.329$ & 0.171 & 3.96 & 0.047 & 74.8 \\
\hline Grade $\geq 3$ & 4 & 7 & 0.566 & $0.165 \sim 1.940$ & 0.365 & 0.02 & 0.899 & 0 \\
\hline
\end{tabular}

ranged between $4 \%$ and $53 \%$, with a pooled rate of $32 \%$ (95\% CI 25-38\%) (Figure 2A). The frequency shifted with the stringency of pCR definitions: $29 \%$ (95\% CI 11 $48 \%$ ) achieved ypT0 ypN0 (Figure 2B), and 39\% (95\% CI 19-58\%) achieved ypT0/is (Figure 2C). ypT0/is ypN0 definition was used in the following analysis.

\section{pCR in subgroup analyses}

As expected, frequency of $\mathrm{pCR}$ in patients with hormone receptor positive, human epidermal growth factor receptor 2 negative(HR+/HER2-) tumors was low (14\%, 95\% CI 11-17\%) (Figure 3A). The more aggressive subtypes triple negative breast cancer (TNBC) $(41 \%, 95 \%$ CI $38-45 \%)$ and HER2+ tumors (54\%, 95\% CI 43-66\%), had increased frequencies of pCR (Figure 3B, 3C). Within 
A Stud $\%$

\section{ID} ES $(95 \% \mathrm{Cl}) \quad$ Weight

Robidoux (2010) Sinclair (2012) Li (2012)

Snider (2013)

Sinclair (2013)

Mrozek (2014)

Shimada (2015)

Connolly (2015)

Huang (2015)

Tanaka (2015)

Gluz (2015)

Kuwayama (2015)

Khan (2015)

Shigematsu (2015)

Somlo (2015)

Untch (2016)

Gianni (2016)

Matsuda (2016)

Khasraw (2016)

Nahleh (2016)

Overall (I-squared $=90.6 \%, p=0.000$ )

NOTE: Weights are from random effects analysis

$-1$

$0.26(0.15,0.37) \quad 5.15$

$0.35(0.22,0.47) \quad 4.88$

$0.28(0.16,0.40) \quad 4.97$

$0.53(0.35,0.71) \quad 4.09$

$0.45(0.32,0.59) \quad 4.76$

$0.18(0.05,0.31) \quad 4.79$

$0.04(-0.01,0.09) \quad 5.80$

$0.27(0.16,0.39) \quad 5.09$

$0.27(0.11,0.42) \quad 4.39$

$0.49(0.34,0.63) \quad 4.58$

$0.36(0.31,0.42) \quad 5.79$

$0.17(0.09,0.26) \quad 5.43$

$0.22(0.08,0.36) \quad 4.62$

$0.37(0.24,0.50) \quad 4.84$

$0.53(0.37,0.69) \quad 4.39$

$0.43(0.39,0.47) \quad 5.89$

$0.23(0.18,0.27) \quad 5.86$

$0.29(0.14,0.44) \quad 4.52$

$0.47(0.32,0.63) \quad 4.45$

$0.28(0.22,0.34) \quad 5.71$

$0.32(0.25,0.38) \quad 100.00$

B

Study

ID

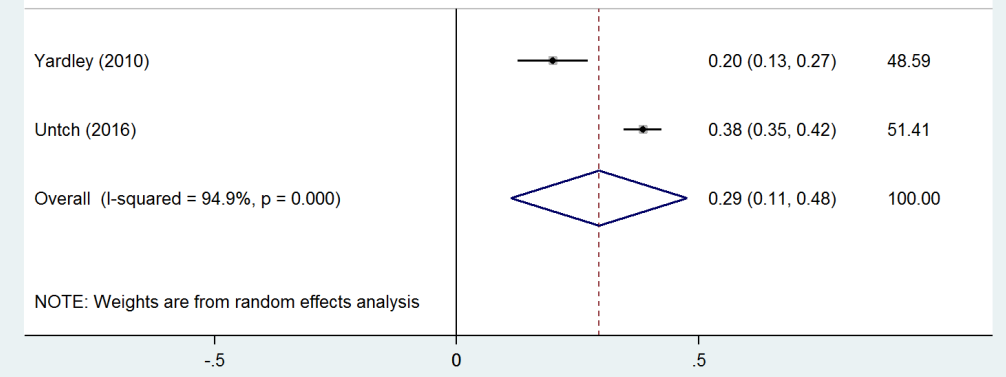

C

Study

ID

Shimada (2015)

Snider (2013)

Robidoux (2010)

Untch (2016)

Khasraw (2016)

Shigematsu (2015)

Overall (I-squared $=96.5 \%, p=0.000)$

NOTE: Weights are from random effects analysis
ES $(95 \% \mathrm{Cl}) \quad$ Weight

$0.06(-0.01,0.12) \quad 17.51$

$0.57(0.39,0.74) \quad 15.47$

$0.29(0.18,0.40) \quad 16.84$

$0.49(0.45,0.53) \quad 17.71$

$0.39(0.26,0.52) \quad 16.48$

$0.39(0.19,0.58) \quad 100.00$
$0.55(0.40,0.70) \quad 15.99$

Figure 2: Forest plots of probability achieving pCR in unselected breast cancer patients with pCR definition of (A) ypT0/isN0; (B) ypT0N0; (C) ypT0/is. 
the HER2+ population, pCR was more common for HRtumors $(61 \%, 95 \% \mathrm{CI} 47-74 \%)$ than for HR+ tumors (40\%, 95\% CI 28-52\%) (Figure 3D, 3E).

\section{Efficacy comparison in randomized trials}

Three randomized trials, including 2,053 breast cancer patients, compared neoadjuvant nab-paclitaxel versus conventional taxane (paclitaxel/docetaxel). Patients with HER2+ disease in GeparSepto trial were also treated with trastuzumab and pertuzumab, while the other two trials both included only HER2- patients. The schedules and dosages of nab-paclitaxel in each study were as below: in GeparSepto trial, patients received nab-paclitaxel $125 \mathrm{mg} / \mathrm{m}^{2}$ continuous weekly for 12 weeks (reduced from the initial dose of $150 \mathrm{mg} / \mathrm{m}^{2}$ after a protocol amendment due to high frequency of grade 3-4 peripheral sensory neuropathy) followed by epirubicin/ cyclophosphamide(EC); in ETNA trial, a lower dose of nab-paclitaxel $125 \mathrm{mg} / \mathrm{m}^{2}$ in 3 out of 4 weeks for 4 cycles followed by EC; and 4 cycles of nab-paclitaxel
$100 \mathrm{mg} / \mathrm{m}^{2}$ every 3 out of 4 weeks followed by 4 cycles of epirubicin,5-fluorouracil and cyclophosphamide. In the control group, taxane regimens were all given at a standard dose or beyond: in GeparSepto trial, patients were administrated with paclitaxel $80 \mathrm{mg} / \mathrm{m}^{2}$ continuous weekly for 12 weeks followed by EC; 4 cycles of paclitaxel $90 \mathrm{mg}$ / $\mathrm{m}^{2}$ every 3 out of 4 weeks followed by EC were given in ETNA trial; 4 cycles of docetaxel $75 \mathrm{mg} / \mathrm{m}^{2}$, every 3-week were given in Kuwayama study. When compared to conventional taxane regimens, patients with neoadjuvant nab-paclitaxel achieved significantly more frequent pCR $(\mathrm{OR}=1.383,95 \% \mathrm{CI} 1.141-1.676, p=0.001)$ (Figure 4A). A funnel plot of the effect size for each randomized trial against the precision showed no asymmetry (Figure 4B), which indicating no potential publication bias.

\section{Toxicity profiles}

Most nab-paclitaxel trials included in our study demonstrated reasonable tolerability profiles. Safety data from randomized GeparSepto and ETNA trial was

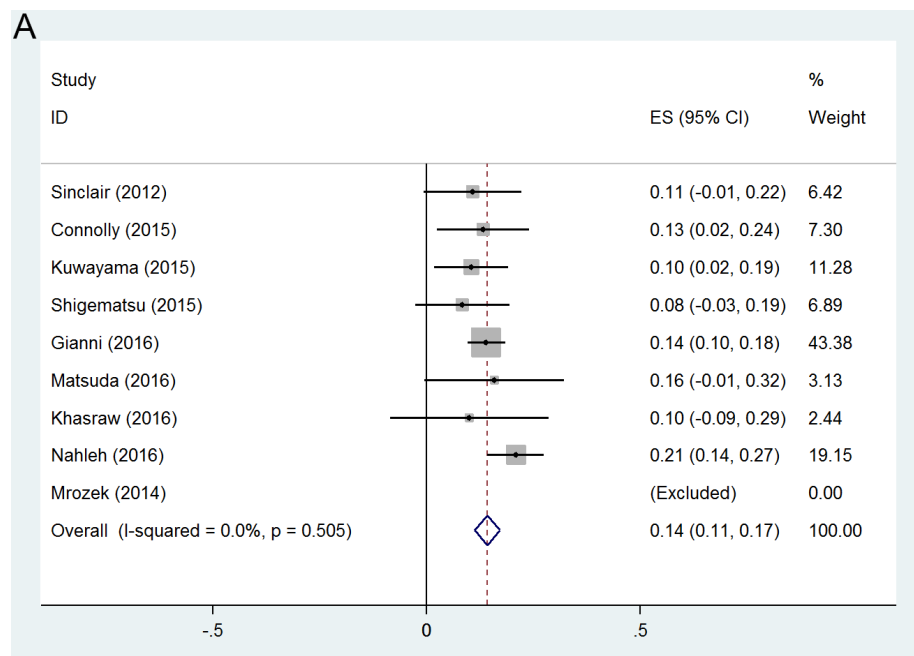

B

\begin{tabular}{|c|c|c|c|}
\hline \multicolumn{3}{|l|}{ Study } & $\%$ \\
\hline ID & & $\mathrm{ES}(95 \% \mathrm{Cl})$ & Weight \\
\hline Sinclair (2012) & $\longrightarrow$ & $0.59(0.41,0.78)$ & 3.77 \\
\hline Snider (2013) & $\rightarrow$ & $0.53(0.35,0.71)$ & 4.07 \\
\hline Mrozek (2014) & & $0.50(0.22,0.78)$ & 1.62 \\
\hline Connolly (2015) & - & $0.50(0.30,0.70)$ & 3.24 \\
\hline Gluz (2015) & $\rightarrow$ & $0.36(0.31,0.42)$ & 47.23 \\
\hline Kuwayama (2015) & $\rightarrow 1$ & $0.30(0.12,0.47)$ & 4.37 \\
\hline Shigematsu (2015) & & $0.62(0.35,0.88)$ & 1.85 \\
\hline Somlo (2015) & $\stackrel{1}{1}$ & $0.53(0.37,0.69)$ & 5.14 \\
\hline Gianni (2016) & $\rightarrow$ & $0.41(0.32,0.51)$ & 15.18 \\
\hline Matsuda (2016) & 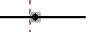 & $0.44(0.19,0.68)$ & 2.19 \\
\hline Khasraw (2016) & $\longrightarrow$ & $0.40(0.15,0.65)$ & 2.11 \\
\hline Nahleh (2016) & $\longrightarrow$ & $0.43(0.31,0.55)$ & 9.21 \\
\hline Overall $(I-$ squared $=30.8 \%, p=0.145)$ & 0 & $0.41(0.38,0.45)$ & 100.00 \\
\hline $\begin{array}{l}1 \\
-1\end{array}$ & & 1 & \\
\hline
\end{tabular}


C

Study $\%$

ID

ES $(95 \% \mathrm{Cl}) \quad$ Weight

\begin{tabular}{|c|c|c|c|}
\hline Li (2012) & $\rightarrow$ & $0.46(0.28,0.65)$ & 19.25 \\
\hline Sinclair (2013) & $\longrightarrow$ & $0.45(0.32,0.59)$ & 24.78 \\
\hline Tanaka (2015) & $\longrightarrow$ & $0.49(0.34,0.63)$ & 23.38 \\
\hline Shigematsu (2015) & & $0.59(0.35,0.82)$ & 14.99 \\
\hline Khasraw (2016) & & $-0.80(0.60,1.00)$ & 17.59 \\
\hline Overall (I-squared $=56.2 \%, p=0.058$ ) & & $0.54(0.43,0.66)$ & 100.00 \\
\hline NOTE: Weights are from random effects analysis & & & \\
\hline
\end{tabular}

D

Study

$\%$

ID

ES $(95 \% \mathrm{Cl}) \quad$ Weight

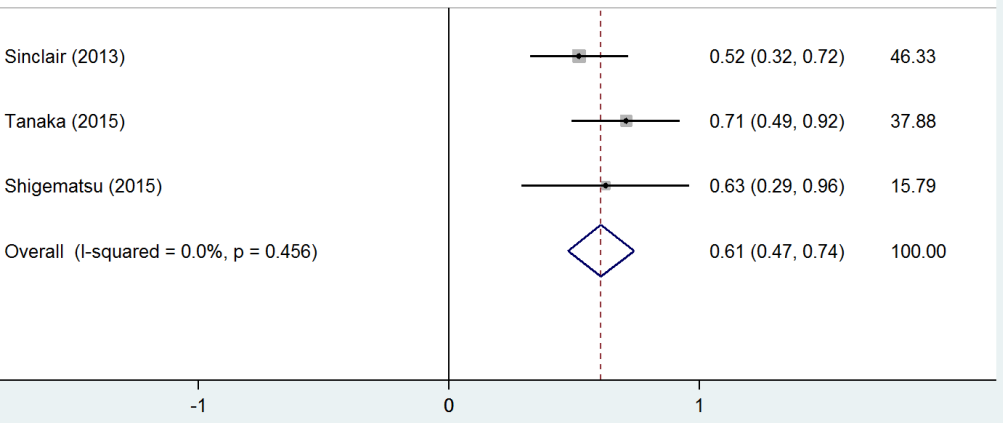

E

Study

ID

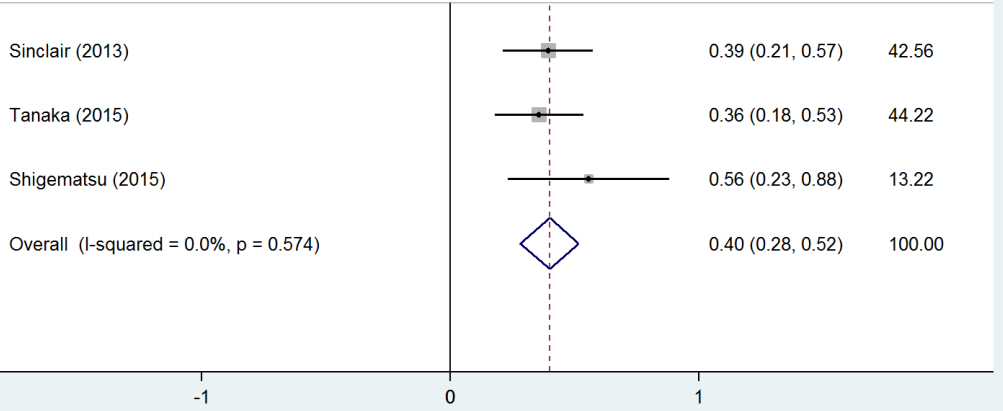

Figure 3: Forest plots of probability achieving pCR(ypT0/isN0) in (A) HR+/HER2- group; (B) TNBC group; (C) HER2+ group; (D) HR+/HER2+ group; (E) HR-/HER2+ group. 
extracted to compare the toxicity profiles of nab-paclitaxel to paclitaxel in the preoperative setting. One thousand eight hundreds and seventy eight patients were eventually included into safety analysis, the numbers of all adverse events and those worse than grade 3 were listed in Table 2.

The hematological toxic effects, neutropenia, leucopenia, increase of alanine aminotransferase, increase of aspartate aminotransferase were generally equivalent but numerically higher in nab-paclitaxel group than paclitaxel group. For non-hematological toxic effect, all grades of peripheral sensory neuropathy occurred more frequently in nab-paclitaxel group as compared to paclitaxel group $(\mathrm{OR}=2.090,95 \% \mathrm{CI} 1.016-4.302, p=$ 0.045). Patients received nab-paclitaxel were 3 times more likely to have severer than grade 3 peripheral sensory neuropathy events $(\mathrm{OR}=3.766,95 \% \mathrm{CI}$ 2.324-6.100, $p<0.001)$. Hypersensitivity was more common with paclitaxel than nab-paclitaxel at any grade and at grades $3-4$, even though that patients in the paclitaxel group already received premedication. Other non-hematological toxic effects, such as nausea, vomiting, fatigue and diarrhea at any grade were identical in two groups.

\section{DISCUSSION}

In this systematic review and meta-analysis, we demonstrate that nab-paclitaxel is an effective cytotoxic drug as in neoadjuvant chemotherapy for primary breast cancer patients, especially in aggressive subtypes. Moreover, this is the first meta-analysis of randomized clinical trials in breast cancer, indicating neoadjuvant nabpaclitaxel significantly improved pCR rate compared to conventional taxanes with generally reasonable toxicity profiles.

In our study, nab-paclitaxel among unselected primary breast cancer patients showed a wide range of pCR rates from $4 \%$ to $53 \%$, with a fairly high overall rate of $32 \%$. It is higher than the pCR rate (ypT0/is N0, $19.8 \%$ ), reported in the German Breast Group (GBG) pooled analysis including seven prospective clinical trials using neoadjuvant anthracycline plus conventional taxane chemotherapy [43]. Additionally, nab-paclitaxel has shown promising early response in neoadjuvant setting. The latest results of ETNA trial showed a clinical overall response rate of $69.4 \%$ after first 4 cycles of single-agent neoadjuvant nab-paclitaxel, even though the improved
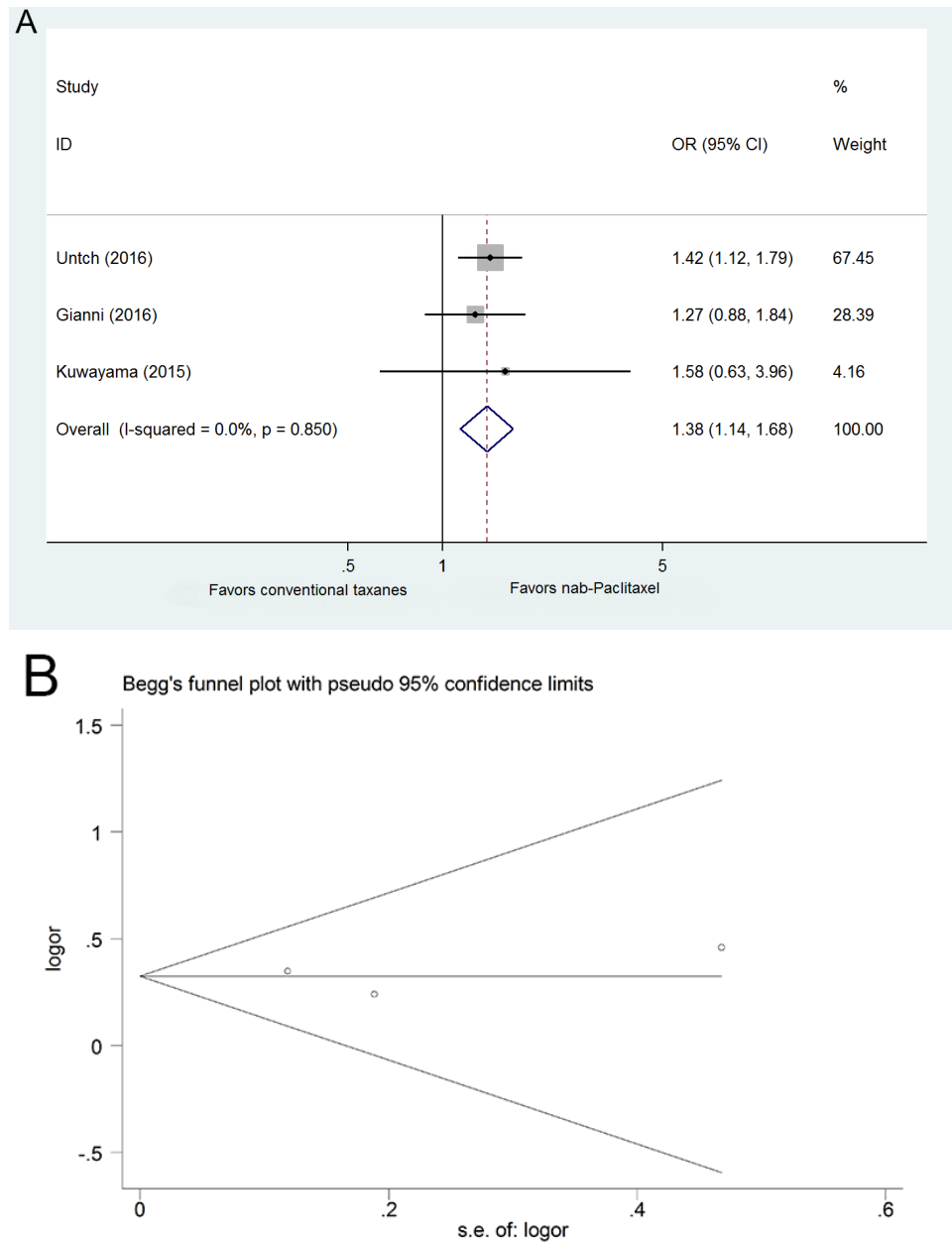

Figure 4: A. Forest plots of odds ratios for pCR within randomized clinical trials. B. Funnel plot. 
pCR rate with nab-paclitaxel did not reach statistical significance [39]. In WSG-ADAPT TN trial, significant tumor necrosis in 3-week re-biopsy was detected in $24 \%$ of the patients after first cycle of nab-paclitaxel, which could contribute to the prediction of pCR rate [33].

Furthermore, patients with more aggressive tumors seemed to benefit from the exchange of nab-paclitaxel. pCR rates in HR-/HER2+ group (61\%, 95\% CI 47-74\%) and TNBC group $(41 \%, 95 \%$ CI 38-45\%) were much higher than those observed in other breast cancer subtypes. Patients with HR+/HER2- breast cancer had the lowest incidence of pCR (14\%, 95\% CI 11-17). Pooled-analysis indicated that $\mathrm{pCR}$ was significantly more common in patients treated with neoadjuvant nab-paclitaxel when compared to conventional, standard dose or beyond taxanes $(\mathrm{OR}=1.383,95 \% \mathrm{CI} 1.141-1.676, p=0.001)$. Of note, in the GeparSepto trial, pCR rate almost doubled in the TNBC cohort treated with nab-paclitaxel compared to paclitaxel [38]. Similarly, TNBC patients treated with first-line nab-paclitaxel in metastatic setting also achieved excellent tumor response [44, 45]. Therefore, nabpaclitaxel might be a reasonable taxane-based regimen for curable TNBC patients due to lack of promising ways to further improve the outcomes, but future study is warranted.

In order to improve the benefit of systemic treatment, predictive biomarkers are important in tailoring individualized anti-cancer therapy. But so far we have failed to identify any subset most likely to benefit from neoadjuvant nab-paclitaxel. Secreted protein acidic and rich in cysteine (SPARC) is an albumin and calcium binding glycoprotein, one of its main function is to facilitate tissue remodeling [46]. Hypothetically, an accumulation of SPARC in breast cancer cells and stroma could increase its ability to bind albumin, therefore might serve as a predictive marker for nab-paclitaxel. In the GeparTrio trial, investigators found that high expression of SPARC in tumor cells was significantly correlated with increased $\mathrm{pCR}$ rate to neoadjuvant chemotherapy [47]. However, in the GeparSepto trial, the benefit difference from neoadjuvant nab-paclitaxel in the SPARCoverexpressing group was not remarkable compared to the SPARC-negative cohort [38]. Data in metastatic setting also failed to prove association between efficacy of nabpaclitaxel and SPARC expression [48]. More evidences from large prospective trials are warranted to find predictive markers for nab-paclitaxel treatment.

In this meta-analysis, nab-paclitaxel has almost identical toxicities as conventional taxanes except peripheral sensory neuropathy. Both any grade and grade 3-4 peripheral sensory neuropathy were significantly more frequent in nab-paclitaxel group compared to the conventional taxane group. In GeparSepto trial, after dose amendment of nab-paclitaxel from 150 to $125 \mathrm{mg} /$ $\mathrm{m}^{2}$ continuous weekly for 12 weeks, the frequency of grade 3-4 peripheral sensory neuropathy in nab-paclitaxel group decreased from $15 \%$ to $8 \%$ [38]; in ETNA trial, when nab-paclitaxel was given $125 \mathrm{mg} / \mathrm{m}^{2}$ every 3 out of 4 weeks for 4 cycles, the frequency of grade 3-4 peripheral sensory neuropathy was $4.5 \%$, which might be one of the explanations that the primary endpoint of this trial, improved pCR after nab-paclitaxel, did not meet statistical significance [39]. Long-term follow-up would be necessary to identify symptom relief patterns and its impact on quality of life.

Notably, in our analysis, patients had less hypersensitivity events in nab-paclitaxel group even though premedication was already given in the conventional group. A few clinical-economic studies supported the cost-effectiveness of nab-paclitaxel in MBC when compared to conventional taxanes since it lowered the incidence of severe adverse events and expenses of managing the critical clinical situations $[49,50]$.

In conclusion, our study demonstrates that nabpaclitaxel is an effective cytotoxic drug in neoadjuvant treatment of breast cancer, especially in patients with aggressive tumors like TNBC and HER2+ diseases. Exchange of neoadjuvant nab-paclitaxel for conventional taxanes could significantly improve the probability of pCR with generally reasonable toxicities.

\section{MATERIALS AND METHODS}

\section{Study selection}

According to the Preferred Reporting Items for Systematic Reviews and Meta-Analyses (PRISMA) guideline [51], a systematic search of Pubmed was performed using the medical subject heading (MeSH) terms "breast neoplasms", as well as the following keywords: (1) breast cancer; AND (2) nab-paclitaxel OR nanoparticle paclitaxel; AND (3) neoadjuvant OR preoperative OR primary systemic. The "related articles" function was used to broaden the search. All abstracts, studies and citations were checked for additional material when appropriate. In addition, abstracts from annual meetings of the American Society of Clinical Oncology (ASCO), European Society of Medical Oncology Conference (ESMO) and San Antonio Breast Cancer Symposium (SABCS) were retrieved for relevant abstracts using similar search terms. No language restrictions were made but all available comparative studies were in English language.

\section{Data extraction}

Two investigators (Y Zong, JY Wu) independently performed the search, reviewed and extracted the following data from each study according to a prespecified protocol: first author, year of publication, study 
demographics, study design, number of subjects, treatment regimen, and end-point data (pCR). Where discrepancies arose, papers were re-examined and consensus was reached by discussion.

\section{Inclusion and exclusion criteria}

Studies included in the analysis had to comply with all of the following criteria:

1. Studies that reported pCR from neoadjuvant nabpaclitaxel-containing regimen in non-metastatic breast cancer patients;

2. Full paper or conference abstract available;

3. Clear definition of pCR (ypT0/is ypN0, ypT0 ypN0, or ypT0/is ypN0/+).

4. More than 30 eligible patients reported.

5 . At least 9 dosages of weekly nab-paclitaxel or 3 cycles of every-3-week nab-paclitaxel.

Studies would be excluded by any one of the following criteria:

1. Studies about adjuvant chemotherapy or metastatic breast cancer;

2. pCR not used as end point for treatment response evaluation;

3. Studies lacking key information.

\section{Outcomes of interest}

The primary endpoint of interest in our study was the total number of patients who achieved pCR, the definition of which varied significantly among the studies included. We conducted our analysis according to each definition of pCR, including ypT0/is ypN0, ypT0 ypN0 and ypT0/is ypN0/+, in order to obtain more detailed and precise results. Besides, comparison of the toxicity profiles of nab-paclitaxel and paclitaxel in randomized trials was also performed.

\section{Statistical analysis}

Aggregate $\mathrm{pCR}$ rates were calculated in the nabpaclitaxel-containing arm and the no-nab-paclitaxel arm. Dichotomous data for each trial were expressed as an odds ratio (OR), with 95\% confidence intervals (CIs). An OR of $>1$ favors the nab-paclitaxel group, and the point estimate of the OR was considered statistically significant at the $\mathrm{P}$ $<0.05$ level if the $95 \%$ CI did not include the value of one. Statistical heterogeneity was calculated using Cochrane's $\mathrm{Q}$ statistic and quantified using the $\mathrm{I}^{2}$ statistic. Pooled estimates of outcomes were calculated using a fixed-effect model (Mantel-Haenszel test) but a random-effect model (DerSimonian-Laird test) was used when heterogeneity was present. The software package STATA (version 14.0, College Station, TX, US) for Windows 10 was used for analysis.

\section{CONFLICTS OF INTEREST}

The authors have no conflicts of interest to report.

\section{FINANCIAL SUPPORT}

This work was supported by YangFan Foundation, Science and Technology Commission of Shanghai Municipality [Grant number:15YF1407200]

\section{REFERENCES}

1. Torre LA, Bray F, Siegel RL, Ferlay J, Lortet-Tieulent J, Jemal A. Global cancer statistics, 2012. CA Cancer J Clin. 2015;65:87-108.

2. Amoroso V, Generali D, Buchholz $\mathrm{T}$, Cristofanilli $\mathrm{M}$, Pedersini R, Curigliano G, Daidone MG, Di Cosimo S, Dowsett M, Fox S, Harris AL, Makris A, Vassalli L, et al. International Expert Consensus on Primary Systemic Therapy in the Management of Early Breast Cancer: Highlights of the Fifth Symposium on Primary Systemic Therapy in the Management of Operable Breast Cancer, Cremona, Italy (2013). J Natl Cancer Inst Monogr. 2015:9096.

3. Cortazar P, Zhang L, Untch M, Mehta K, Costantino JP, Wolmark N, Bonnefoi H, Cameron D, Gianni L, Valagussa P, Swain SM, Prowell T, Loibl S, et al. Pathological complete response and long-term clinical benefit in breast cancer: the CTNeoBC pooled analysis. Lancet. 2014;384:164-172.

4. von Minckwitz G, Untch M, Blohmer JU, Costa SD, Eidtmann H, Fasching PA, Gerber B, Eiermann W, Hilfrich J, Huober J, Jackisch C, Kaufmann M, Konecny GE, et al. Definition and impact of pathologic complete response on prognosis after neoadjuvant chemotherapy in various intrinsic breast cancer subtypes. J Clin Oncol. 2012;30:1796-1804.

5. Early Breast Cancer Trialists' Collaborative Group (EBCTCG), Peto R, Davies C, Godwin J, Gray R, Pan HC, Clarke M, Cutter D, Darby S, McGale P, Taylor C, Wang YC, Bergh J, et al. Comparisons between different polychemotherapy regimens for early breast cancer: metaanalyses of long-term outcome among 100,000 women in 123 randomised trials. Lancet. 2012;379:432-444.

6. Bear HD, Anderson S, Brown A, Smith R, Mamounas EP, Fisher B, Margolese R, Theoret H, Soran A, Wickerham DL, Wolmark N; National Surgical Adjuvant Breast and Bowel Project Protocol B-27. The effect on tumor response of adding sequential preoperative docetaxel to preoperative doxorubicin and cyclophosphamide: preliminary results from National Surgical Adjuvant Breast and Bowel Project Protocol B-27. J Clin Oncol. 2003;21:4165-4174.

7. Gianni L, Eiermann W, Semiglazov V, Manikhas A, Lluch 
A, Tjulandin S, Zambetti M, Vazquez F, Byakhow M, Lichinitser M, Climent MA, Ciruelos E, Ojeda B, et al. Neoadjuvant chemotherapy with trastuzumab followed by adjuvant trastuzumab versus neoadjuvant chemotherapy alone, in patients with HER2-positive locally advanced breast cancer (the NOAH trial): a randomised controlled superiority trial with a parallel HER2-negative cohort. Lancet. 2010;375:377-384.

8. Baselga J, Bradbury I, Eidtmann H, Di Cosimo S, de Azambuja E, Aura C, Gómez H, Dinh P, Fauria K, Van Dooren V, Aktan G, Goldhirsch A, Chang TW, et al. Lapatinib with trastuzumab for HER2-positive early breast cancer (NeoALTTO): a randomised, open-label, multicentre, phase 3 trial. Lancet. 2012;379:633-640.

9. Robidoux A, Tang G, Rastogi P, Geyer CE Jr, Azar CA, Atkins JN, Fehrenbacher L, Bear HD, Baez-Diaz L, Sarwar S, Margolese RG, Farrar WB, Brufsky AM,et al. Lapatinib as a component of neoadjuvant therapy for HER2positive operable breast cancer (NSABP protocol B-41): an open-label, randomised phase 3 trial. Lancet Oncol. 2013;14:1183-1192.

10. Earl HM, Vallier AL, Hiller L, Fenwick N, Young J, Iddawela M, Abraham J, Hughes-Davies L, Gounaris I, McAdam K, Houston S, Hickish T, Skene A, et al. Effects of the addition of gemcitabine, and paclitaxel-first sequencing, in neoadjuvant sequential epirubicin, cyclophosphamide, and paclitaxel for women with high-risk early breast cancer (Neo-tAnGo): an open-label, $2 \times 2$ factorial randomised phase 3 trial. Lancet Oncol. 2014;15:201-212.

11. von Minckwitz G, Schneeweiss A, Loibl S, Salat C, Denkert C, Rezai M, Blohmer JU, Jackisch C, Paepke S, Gerber B, Zahm DM, Kümmel S, Eidtmann H, et al. Neoadjuvant carboplatin in patients with triple-negative and HER2positive early breast cancer (GeparSixto; GBG 66): a randomised phase 2 trial. Lancet Oncol. 2014;15:747-756.

12. Sikov WM, Berry DA, Perou CM, Singh B, Cirrincione CT, Tolaney SM, Kuzma CS, Pluard TJ, Somlo G, Port ER, Golshan M, Bellon JR, Collyar D, et al. Impact of the addition of carboplatin and/or bevacizumab to neoadjuvant once-per-week paclitaxel followed by dose-dense doxorubicin and cyclophosphamide on pathologic complete response rates in stage II to III triple-negative breast cancer: CALGB 40603 (Alliance). J Clin Oncol. 2015;33:13-21.

13. Carey LA, Berry DA, Cirrincione CT, Barry WT, Pitcher BN, Harris LN, Ollila DW, Krop IE, Henry NL, Weckstein DJ, Anders CK, Singh B, Hoadley KA, et al. Molecular Heterogeneity and Response to Neoadjuvant Human Epidermal Growth Factor Receptor 2 Targeting in CALGB 40601, a Randomized Phase III Trial of Paclitaxel Plus Trastuzumab With or Without Lapatinib. J Clin Oncol. 2016;34:542-549.

14. ten Tije AJ, Verweij J, Loos WJ, Sparreboom A. Pharmacological effects of formulation vehicles : implications for cancer chemotherapy. Clin Pharmacokinet. 2003;42:665-685.
15. Taxol (paclitaxel) injection label-FDA. Available at: http://www.accessdata.fda.gov/drugsatfda_docs/ label/2011/020262s049lbl.pdf; 2016 [accessed 14.09.16].

16. ABRAXANE® for Injectable Suspension (paclitaxel protein-bound particles for injectable suspension) (albumin-bound) Available at: http://www.accessdata.fda. gov/drugsatfda_docs/label/2013/021660s037lbl.pdf; 2016 [accessed 14.09.16]

17. Desai N, Trieu V, Yao Z, Louie L, Ci S, Yang A, Tao C, De T, Beals B, Dykes D, Noker P, Yao R, Labao E, et al. Increased antitumor activity, intratumor paclitaxel concentrations, and endothelial cell transport of cremophorfree, albumin-bound paclitaxel, ABI-007, compared with cremophor-based paclitaxel. Clin Cancer Res. 2006;12:1317-1324.

18. Gradishar WJ, Tjulandin S, Davidson N, Shaw H, Desai N, Bhar P, Hawkins M, O'Shaughnessy J. Phase III trial of nanoparticle albumin-bound paclitaxel compared with polyethylated castor oil-based paclitaxel in women with breast cancer. J Clin Oncol. 2005;23:7794-7803.

19. Gradishar WJ, Krasnojon D, Cheporov S, Makhson AN, Manikhas GM, Clawson A, Bhar P. Significantly longer progression-free survival with nab-paclitaxel compared with docetaxel as first-line therapy for metastatic breast cancer. J Clin Oncol. 2009;27:3611-3619.

20. Roy V, LaPlant BR, Gross GG, Bane CL, Palmieri FM; North Central Cancer Treatment Group. Phase II trial of weekly nab (nanoparticle albumin-bound)-paclitaxel (nabpaclitaxel) (Abraxane) in combination with gemcitabine in patients with metastatic breast cancer (N0531). Ann Oncol. 2009;20:449-453.

21. Lobo C, Lopes G, Baez O, Castrellon A, Ferrell A, Higgins C, Hurley E, Hurley J, Reis I, Richman S, Seo P, Silva $\mathrm{O}$, Slingerland J, et al. Final results of a phase II study of nab-paclitaxel, bevacizumab, and gemcitabine as first-line therapy for patients with HER2-negative metastatic breast cancer. Breast Cancer Res Treat. 2010;123:427-435.

22. Robidoux A, Buzdar AU, Quinaux E, Jacobs S, Rastogi P, Fourchotte V, Younan RJ, Pajon ER, Shalaby IA, Desai AM, Fehrenbacher L, Geyer CE Jr, Mamounas EP, et al. A phase II neoadjuvant trial of sequential nanoparticle albuminbound paclitaxel followed by 5-fluorouracil/ epirubicin/cyclophosphamide in locally advanced breast cancer. Clin Breast Cancer. 2010;10:81-86.

23. Yardley DA, Zubkus J, Daniel B, Inhorn R, Lane CM, Vazquez ER, Naot Y, Burris HA 3rd, Hainsworth JD. A phase II trial of dose-dense neoadjuvant gemcitabine, epirubicin, and albumin-bound paclitaxel with pegfilgrastim in the treatment of patients with locally advanced breast cancer. Clin Breast Cancer. 2010,10:367-372.

24. Sinclair NF, Abu-Khalaf MM, Rizack T, Rosati K, Chung $\mathrm{G}$, Legare RD

DiGiovanna M, Fenton MA, Bossuyt V, Strenger R, Bachir Joseph Sakr, Donald R. Lannin, Jennifer S, et al. Neoadjuvant weekly nab-paclitaxel, carboplatin plus 
bevacizumab with or without dose-dense doxorubicincyclophosphamide (ddAC) plus bevacizumab in ER+/ HER2-negative $(\mathrm{HR}+)$ and triple-negative breast cancer: a BrUOG study. J Clin Oncol. 2010,30(suppl) [abstract1045].

25. Li SM, Wu X, Frankel PH, Gao H, Sun G, Snoo FD, Rossi J, Wang E, Roepman P, Yen Y, PeetersJ, Stork L, Somlo G. Correlation between miRNA (miR) and gene expression profiles (GEP) and response to neoadjuvant chemotherapy (NT) in patients with locally advanced and nflammatory breast cancer (BC). J Clin Oncol. 2010,30(suppl) [abstract 10545].

26. Snider JN, Schwartzberg L, Young RR, Yunus F, Allen JW, Verrier C, Yunus F, Verrier CS,Jahanzeb M. Pathologic complete response (pCR) with weekly nanoparticle albumin bound (nab-P) plus carboplatin $(\mathrm{C})$ followed by doxorubicin plus cyclophosphamide (AC) with concurrent bevacizumab (B) for triple-negative breast cancer (TNBC). J Clin Oncol. 2013,31(suppl) [abstract 1068].

27. Sinclair NF, Sakr BJ, Abu-Khalaf MM, Somlo G, Black RC, Chung GG, Rizack T, Strenger R, Fenton MA, DiGiovanna M, Constantinou M, Lannin DR, Legare $\mathrm{RD}$, et al. Multicenter phase II trial of neoadjuvant carboplatin, weekly nabpaclitaxel, and trastuzumab in stage II-III HER2+ breast cancer: a BrUOG study. J Clin Oncol.2013,31(suppl) [abstract 619].

28. Mrózek E, Layman R, Ramaswamy B, Lustberg M, Vecchione A, Knopp MV, Shapiro CL. Phase II trial of neoadjuvant weekly nanoparticle albumin-bound paclitaxel, carboplatin, and biweekly bevacizumab therapy in women with clinical stage II or III HER2-negative breast cancer. Clin Breast Cancer.2014,14:228-234.

29. Shimada H, Ueda S, Saeki T, Shigekawa T, Takeuchi H, Hirokawa E, Sugitani I, Sugiyama M, Takahashi T, Matsuura K, Yamane T, Kuji I, et al. Neoadjuvant triweekly nanoparticle albumin-bound paclitaxel followed by epirubicin and cyclophosphamide for stage II/III HER2negative breast cancer: evaluation of efficacy and safety. Jpn J Clin Oncol. 2015,45:642-649.

30. Connolly RM, Leal JP, Goetz MP, Zhang Z, Zhou XC, Jacobs LK, Mhlanga J, O JH, Carpenter J, Storniolo AM, Watkins S, Fetting JH, Miller RS, et al. TBCRC 008: early change in $18 \mathrm{~F}-\mathrm{FDG}$ uptake on PET predicts response to preoperative systemic therapy in human epidermal growth factor receptor 2-negative primary operable breast cancer. J Nucl Med. 2015,56:31-37.

31. Huang L, Chen S, Yao L, Liu G, Wu J, Shao Z. Phase II trial of weekly nab-paclitaxel and carboplatin treatment with or without trastuzumab as nonanthracycline neoadjuvant chemotherapy for locally advanced breast cancer. Int J Nanomed.2015,10:1969-1975.

32. Tanaka S, Iwamoto M, Kimura K, Matsunami N, Morishima H, Yoshidome K, Nomura T, Morimoto T, Yamamoto D, Tsubota Y, Kobayashi T, Uchiyama K. Phase II study of neoadjuvant anthracycline-based regimens combined with nanoparticle albumin-bound paclitaxel and trastuzumab for human epidermal growth factor receptor 2-positive operable breast cancer. Clin Breast Cancer. 2015,15:191-196.

33. Gluz O, Nitz U, Liedtke C, Christgen M, Sotlar K, Grischke E, Forstbauer H, Braun M, Warm M, Hackmann J, Uleer C, Aktas B, Schumacher C, et al. Comparison of 12 weeks neoadjuvant nabpaclitaxel combined with carboplatinum vs. gemcitabine in triplenegative breast cancer: WSGADAPT TN randomized phase II trial. Presented at 2015 San Antonio Breast Cancer Symposium [abstract S6-07].

34. Kuwayama T, Yamauchi $\mathrm{H}$, Takano T, Tsugawa $\mathrm{K}$, Sato T, Kitani A, Hayashi N, Okuyama H, Nakamura S. Primary analysis of a randomized phase II, multicenter trial: Neoadjuvant weekly nab-paclitaxel $100 \mathrm{mg} / \mathrm{m} 2$ followed by FE100C compared with docetaxel $75 \mathrm{mg} / \mathrm{m} 2$ followed by FE100C for early breast cancer in Japan. J Clin Oncol.2015,33(suppl) [abstract 136].

35. Khan QJ, O’Dea A, Fabian CJ, Connor CS, McGinness M, Mammen JMV, Wagner JL, Baccaray S, Springer M, Yeh $\mathrm{H}$, Sharma P. Neoadjuvant chemotherapy plus trastuzumab in stage II/III breast cancer with low HER2 expression. J Clin Oncol.2015,33(suppl) [abstract 1039].

36. Shigematsu H, Kadoya T, Masumoto N, Sasada T, Emi A, Ohara M, Kajitani K, Okada M. The efficacy and safety of preoperative chemotherapy with triweekly abraxane and cyclophosphamide followed by 5-fluorouracil, epirubicin, and cyclophosphamide therapy for resectable breast cancer: a multicenter clinical trial. Clin Breast Cancer.2015,15:110-116.

37. Somlo G, Chung S, Frankel P, Hurria A, Koehler S, Kruper L, Mortimer JE E, Paz B, Robinson K, Taylor L, Vito C, Waisman J, Yeon C, et al. Phase II trial of neoadjuvant chemotherapy with carboplatin and nab-paclitaxel in patients with triple negative locally advanced and inflammatory breast cancer. Presented at 2015 San Antonio Breast Cancer Symposium [abstract P1-14-10].

38. Untch $\mathrm{M}$, Jackisch $\mathrm{C}$, Schneeweiss A, Conrad B, Aktas B, Denkert C, Eidtmann H, Wiebringhaus H, Kümmel S, Hilfrich J, Warm M, Paepke S, Just M, et al. Nabpaclitaxel versus solvent-based paclitaxel in neoadjuvant chemotherapy for early breast cancer (GeparSepto-GBG 69): a randomised, phase 3 trial. Lancet Oncol.2016,17:345-356.

39. Gianni L, Mansutti M, Anton A, Calvo L, Bisagni G, Bermejo B, Semiglazov V, Thill M, Chacon JI, Chan A, Morales S, Alvarez I, Plazaola A, et al. ETNA (Evaluating Treatment with Neoadjuvant Abraxane) randomized phase III study comparing neoadjuvant nabpaclitaxel (nab-P) versus paclitaxel (P) both followed by anthracycline regimens in women with HER2-negative high-risk breast cancer: A MICHELANGO study. J Clin Oncol.2016,34(suppl) [abstract 502].

40. Matsuda N, Wang X, Krishnamurthy S, Alvarez RH, Willey JS, Lim B, Parker CA, Babiera G, Booser DJ, Murray JL, Arun B, Brewster AM, Reuben JM, et al. Phase II study of panitumumab, nab-paclitaxel, and carboplatin followed 
by FEC neoadjuvant chemotherapy for patients with primary HER2-negative inflammatory breast cancer. J Clin Onco.2016,34(suppl) [abstract 1087].

41. Khasraw M, Mukaro VR, West L, White K, Rippy E, Brandt C, Tobler R, Murphy CC, Collins IM, BaronHay SE, Ashley DM, Patil S. Tailored neoadjuvant epirubicin and cyclophosphamide (EC) and nanoparticle albumin-bound paclitaxel (nab-P) in breast cancer. J Clin Oncol.2016,34(suppl) [abstract e12515].

42. Nahleh ZA, Barlow WE, Hayes DF, Schott AF, Gralow JR, Sikov WM, Perez EA, Chennuru S, Mirshahidi HR, Corso SW, Lew DL, Pusztai L, Livingston RB, et al. SWOG S0800 (NCI CDR0000636131): addition of bevacizumab to neoadjuvant nab-paclitaxel with dose-dense doxorubicin and cyclophosphamide improves pathologic complete response (pCR) rates in inflammatory or locally advanced breast cancer. Breast Cancer Res Treat.2016,158:485-495.

43. von Minckwitz G, Untch M, Blohmer JU, Costa SD, Eidtmann H, Fasching PA, Gerber B, Eiermann W, Hilfrich J, Huober J, Jackisch C, Kaufmann M, Konecny $\mathrm{GE}$, et al. Definition and impact of pathologic complete response on prognosis after neoadjuvant chemotherapy in various intrinsic breast cancer subtypes. J Clin Oncol. 2012;30:1796-1804.

44. Lobo C, Lopes G, Baez O, Castrellon A, Ferrell A, Higgins C, Hurley E, Hurley J, Reis I, Richman S, Seo P, Silva $\mathrm{O}$, Slingerland J, et al. Final results of a phase II study of nab-paclitaxel, bevacizumab, and gemcitabine as first-line therapy for patients with HER2-negative metastatic breast cancer. Breast Cancer Res Treat. 2010;123:427-435.

45. Hamilton E, Kimmick G, Hopkins J, Marcom PK, Rocha G, Welch R, Broadwater G, Blackwell K. Nab-paclitaxel/ bevacizumab/carboplatin chemotherapy in first-line triple negative metastatic breast cancer. Clin Breast Cancer. 2013;13:416-420.
46. Tremble PM, Lane TF, Sage EH, Werb Z. SPARC, a secreted protein associated with morphogenesis and tissue remodeling, induces expression of metalloproteinases in fibroblasts through a novel extracellular matrix-dependent pathway. J Cell Biol. 1993;121:1433-1444.

47. Lindner JL, Loibl S, Denkert C, Ataseven B, Fasching PA, Pfitzner BM, Gerber B, Gade S, Darb-Esfahani S, Sinn BV, Huober J, Engels K, Tesch H, Karn T, Pommerenke F, Liedtke $\mathrm{C}$, et al. Expression of secreted protein acidic and rich in cysteine (SPARC) in breast cancer and response to neoadjuvant chemotherapy. Ann Oncol. 2015;26:95-100.

48. Schneeweiss A, Seitz J, Smetanay K, Schuetz F, Jaeger D, Bachinger A, Zorn M, Sinn HP, Marmé F. Efficacy of nab-paclitaxel does not seem to be associated with SPARC expression in metastatic breast cancer. Anticancer Res. 2014;34:6609-6615.

49. Dranitsaris G, Coleman R, Gradishar W. nab-Paclitaxel weekly or every 3 weeks compared to standard docetaxel as first-line therapy in patients with metastatic breast cancer: an economic analysis of a prospective randomized trial. Breast Cancer Res Treat. 2010;119:717-724.

50. Dranitsaris G, Cottrell W, Spirovski B, Hopkins S. Economic analysis of albumin-bound paclitaxel for the treatment of metastatic breast cancer. J Oncol Pharm Pract. 2009;15:67-78.

51. Moher D, Liberati A, Tetzlaff J, Altman DG; PRISMA Group. Preferred reporting items for systematic reviews and meta-analyses: the PRISMA statement. BMJ. 2009;339:b2535. 